Dear author,

Please note that changes made in the online proofing system will be added to the article before publication but are not reflected in this PDF.

We also ask that this file not be used for submitting corrections. 


\title{
Liquid fructose in Western-diet-fed mice impairs liver insulin signaling and causes cholesterol and triglyceride loading without changing calorie intake and body

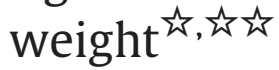

\author{
Miguel Baena ${ }^{\mathrm{a}, \mathrm{b}, 1}$, Gemma Sangüesa ${ }^{\mathrm{a}, \mathrm{b}, 1}$, Natalia Hutter ${ }^{\mathrm{a}}$, José María Beltrán ${ }^{\mathrm{a}}$, Rosa María Sánchez ${ }^{\mathrm{a}, \mathrm{b}, \mathrm{c}}$, \\ Núria Roglans ${ }^{\mathrm{a}, \mathrm{b}, \mathrm{c}}$, Marta Alegret ${ }^{\mathrm{a}, \mathrm{b}, \mathrm{c}, *, 1}$, Juan Carlos Laguna ${ }^{\mathrm{a}, \mathrm{b}, \mathrm{c}, *, 1}$ \\ ${ }^{a}$ Department of Pharmacology, Toxicology and Therapeutic Chemistry, School of Pharmacy and Food Science, University of Barcelona, Spain \\ ${ }^{\mathrm{b}}$ Institute of Biomedicine University of Barcelona, Spain \\ ${ }^{\mathrm{c}}$ Centro de Investigación Biomédica en Red de Fisiopatología de la Obesidad y Nutrición (CIBERObn), Spain \\ Received 14 June 2016; received in revised form 24 October 2016; accepted 27 October 2016
}

\section{Abstract}

Background/objectives: Liquid fructose associates with prevalence of type 2 diabetes mellitus and obesity. Intervention studies suggest that metabolically unfit individuals are more responsive than healthy individuals to liquid fructose. We determined whether mice consuming an obesogenic Western diet were more responsive than chow-fed mice to the alterations induced by liquid fructose supplementation (LFS).

Methods: C57BL/6N mice were fed chow or Western diet \pm ad libitum $15 \%$ fructose solution for 12 weeks. Food and liquid intake and body weight were monitored. Plasma analytes and liver lipids, histology and the expression of genes related to lipid handling, endoplasmic reticulum stress, inflammation and insulin signaling were analyzed.

Results: Western diet increased energy intake, visceral adipose tissue (vWAT), body weight, plasma and liver triglycerides and cholesterol, and inflammatory markers in vWAT vs. chow-fed mice. LFS did not change energy intake, vWAT or body weight. LFS significantly increased plasma and liver triglycerides and cholesterol levels only in Western-diet-fed mice. These changes associated with a potentiation of the increased liver expression of PPAR $\gamma$ and CD36 that was observed in Western-fed mice and related to the increased liver mTOR phosphorylation induced by LFS. Furthermore, LFS in Western-diet-fed mice induced the largest reduction in liver IRS2 protein and a significant decrease in whole-body insulin sensitivity.

Conclusions: LFS in mice, in a background of an unhealthy diet that already induces fatty liver visceral fat accretion and obesity, increases liver lipid burden, hinders hepatic insulin signaling and diminishes whole-body insulin sensitivity without changing energy intake.

(c) 2016 Published by Elsevier Inc.

Keywords: ChREBP; IRS2; PPAR $\gamma$; CD36; mTOR; Visceral adipose tissue; Leptin

\section{Introduction}

Epidemiological studies indicate that the increased consumption of sugar-sweetened beverages is one of the key lifestyle modifications

\footnotetext{
this work was supported by grants from the Fundació Privada Catalana de Nutrició i Lípids, the Ministry of Economy and Competition (SAF2013-42982-R) and European Commission FEDER funds. Miguel Baena and Gemma Sangüesa were supported by FPI and FPU grants, respectively, from the Spanish Ministry of Science and Innovation. We are a Consolidated Research Group of the Autonomous Government of Catalonia (SGR13-00066).

故 We declare no potential conflict of interest, including related consultancies, shareholdings and funding.

* Corresponding authors at: Department of Pharmacology, Toxicology and Therapeutic Chemistry, School of Pharmacy and Food Science, University of Barcelona, Avda. Joan XXIII s.n. Barcelona 08028, Spain. Tel: +34 934024530.

E-mail addresses: alegret@ub.edu (M. Alegret), jclagunae@ub.edu (J.C. Laguna).

${ }^{1}$ These authors contributed equally to this work.
}

that occurred in the last decades that is associated to the increased 33 prevalence of metabolic diseases, such as type 2 diabetes mellitus 34 (T2DM) and obesity, in human populations all over the world [1,2]. 35 Epidemiological studies in humans rely on data obtained from 36 populations with a broad spectrum of genetic predisposition to 37 metabolic diseases and highly varied dietary patterns. In addition, 38 intervention studies in humans, although limited in duration and the 39 number of participants, indicate that metabolically unfit individuals, 40 for example, obese people, are more responsive than healthy people to 41 the metabolic alterations induced by fructose ingestion [3-5]. Given 42 the difficulties in performing intervention studies in humans in terms 43 of design, cost and ethics, there is intense debate over the 44 interpretation of these epidemiological studies on whether they are 45 just merely detecting metabolic disturbances associated with exces- 46 sive calorie intake or reflecting specific deleterious effects related to 47 the way these calories are provided (liquid beverages), the very nature 48 of the simple sugars used (fructose, glucose, sucrose, etc.) or the 49 combination of both. 
Using healthy rodents maintained on solid diets supplemented with liquid solutions of simple sugars has shown that fructose consumption, when compared to equicaloric amounts of glucose consumption, is unique in inducing specific metabolic disturbances in the liver by affecting fatty acid metabolism and insulin signaling pathways [6,7]. Further, we have previously shown that liquid fructose supplementation, at a concentration below $30 \%$ (weight/volume) that has been shown to significantly alter intestinal permeability $[8,9]$, significantly increased atherosclerosis and liver and plasma lipid content in $\mathrm{LDLR}^{-1-}$ mice fed Western-type diet despite ingesting exactly the same amount of calories as $\mathrm{LDLR}^{-1-}$ mice on Western-type diet only [10]. As these transgenic animals already presented a large fat deposition in the liver even when raised with standard rodent chow, we sought to investigate the metabolic response to the combined Western-diet feeding and liquid fructose supplementation in the background wild-type mice lineage used to generate the transgenic LDLR ${ }^{-1-}$ mice we have previously used.

Here we show in a mouse model susceptible to diet-induced metabolic disturbances, the $\mathrm{C} 57 \mathrm{BL} / 6 \mathrm{~N}$ mouse, that liquid fructose supplementation increases liver cholesterol and triglyceride burden, hinders hepatic insulin signaling and diminishes whole-body insulin sensitivity in mice with an unhealthy, Western-style solid diet that already induces fatty liver, visceral fat accretion and obesity. Fructose elicited these changes without affecting the total amount of energy consumed, as fructose-supplemented animals reduced their solid food intake to accommodate the ingested liquid calories.

\section{Materials and methods}

\subsection{Animals and experimental design}

Male mice (C57BL/6N) were purchased from Charles River (France) and maintained with water and food ad libitum at constant humidity and temperature with a light/dark cycle of $12 \mathrm{~h}$. After 3 weeks of acclimatizing, animals were randomly separated into 4 groups of 12 mice each which received (a) control rodent diet without supplementary sugar: control group (C), (b) control rodent diet supplemented with $15 \%$ weight/ volume fructose in drinking water: fructose-supplemented group (F), (c) Western-type diet without supplementary sugar: Western group (W) and (d) Western-type diet supplemented with $15 \%$ weight/volume fructose in drinking water: Western plus fructose group $(\mathrm{W}+\mathrm{F})$. The composition of control (2018 Teklad Global 18\% protein, Harlan Laboratories) and Western-type (D12079B Open Source Diets, Research Diets, Inc.) diets was as detailed previously [10]. During a feeding period of 12 weeks, consumed food and beverage were measured every 2 days and body weight once a week. At the end of the study, animals were sacrificed under intraperitoneal ketamine $(100 \mathrm{mg} / \mathrm{kg}) /$ xylazine $(10 \mathrm{mg} / \mathrm{kg})$ anesthesia between 9 and 10 a.m. after being fasted for $2 \mathrm{~h}$. All procedures were conducted in accordance with the guidelines established by the University of Barcelona's Bioethics Committee, as stated in Law 5/1995 (21st July) from the Generalitat de Catalunya. These guidelines follow the Directive 2010/63/EU of the European Parliament on the protection of animals used for scientific purposes.

\subsection{Sample preparation}

Blood samples were obtained by intracardiac punction at the time of death and collected in microtubes containing anticoagulant as additive (Sarstedt AG \& Co, Nümbrecht, Germany). Plasma was obtained by centrifugation and stored at $-80^{\circ} \mathrm{C}$ until used. Liver and visceral adipose tissues were excised and fractionated. Ten to 100 mg was immediately frozen in liquid $\mathrm{N}_{2}$ and stored at $-80^{\circ} \mathrm{C}$ until used for protein and total RNA extraction. Another portion for hepatic histological analysis was obtained. An additional section of liver tissue $(100 \mathrm{mg})$ was perfused and stored at $-80^{\circ} \mathrm{C}$ for quantifying liver lipids content. Total and nuclear protein extracts from liver and visceral adipose tissue were isolated by the Helenius method [11], and protein concentrations were determined by the Bradford method [12].

\subsection{Glucose, lipids, cholesterol, insulin and leptin analysis}

Plasma glucose, triglycerides and cholesterol levels were measured using an Accutrend Plus System glucometer (Roche Farma, Barcelona, Spain). Plasma leptin and insulin levels were determined at the end of treatment using the EZRL-83K and EZRMI13K kits from Millipore (Billerica, MA, USA), respectively. Insulin sensitivity index (ISI) was calculated as described by Qu et al. [13].

Liver lipids were extracted according to the Bligh and Dyer [14] method using the homogenate fraction. The lipid extract was evaporated under a stream of nitrogen gas and dissolved in absolute ethanol. Triglycerides and cholesterol contents in liver were determined by using colorimetric tests: Triglycerides-LQ no. 41030 and Cholesterol 117 CHOD-POD no. 1001091 from Spinreact (Girona, Spain), respectively.

Total RNA was isolated from $60 \mathrm{mg}$ of liver and adipose tissue using Trizol reagent 120 (Invitrogen, Thermo-Fisher Scientific Inc., MA, USA) in accordance with the manufac- 121 turer's guidelines. Single-stranded cDNA was synthesized by mixing $1 \mu \mathrm{g}$ of liver total RNA, 122 $125 \mathrm{ng}$ of random hexamers (Roche Farma, SA, Madrid, Spain) as primers in the presence 123 of $5 \times$ First-Strand Buffer, $10 \mathrm{mM}$ dithiothreitol, $200 \mathrm{U}$ of Moloney murine leukemia virus 124 reverse transcriptase (M-MLV RT, Invitrogen), $20 \mathrm{U}$ of RNase OUT from Invitrogen and 0.5125 $\mathrm{mM}$ of each dNTP (Sigma-Aldrich, St. Louis, MO, USA) in a total volume of $20 \mu$ l. Samples 126 were incubated at $37^{\circ} \mathrm{C}$ for $60 \mathrm{~min}$ in MJ Mini Personal Thermal Cycler (Bio-Rad, Hercules, 127 CA, USA). The PCR was carried out in StepOnePlus Real-Time PCR System Thermal Cycling 128 Block (Applied Biosystems, Foster City, CA, USA). Twenty microliters of reaction mixture 129 contained Power SYBR Green PCR Master Mix (Applied Biosystems), $100 \mathrm{nM}$ of each 130 specific primer (including forward and reverse primers) and $20 \mathrm{ng}$ of cDNA for each gene. 131 After an initial denaturation at $95^{\circ} \mathrm{C}$ for $10 \mathrm{~min}, 40$ cycles of amplification were done. PCRs 132 were performed in duplicate and normalized to a housekeeping gene, the TATA box 133 binding protein $(t b p)$ gene, using the $2^{-\Delta \Delta \mathrm{Ct}}$ method. The GenBank number, primer 134 sequences and PCR product length are listed in Table 1.

Thirty micrograms of different protein fractions from rat livers was subjected to 137 sodium dodecyl sulfate polyacrylamide gel electrophoresis. Proteins were then 138 transferred to Immobilon polyvinylidene difluoride transfer membranes (Millipore, 139 Billerica, MA, USA), blocked for $1 \mathrm{~h}$ at room temperature with 5\% nonfat milk solution in 140 0.1\% Tween-20-Tris-buffered saline (TBS) and incubated as described previously [6]. 141 Detection was performed using the ECL chemiluminescence kit for HRP (Amersham GE 142 Healthcare Europe GmbH, Barcelona, Spain). To confirm the uniformity of protein 143 loading, blots were incubated with $\beta$-tubulin or $\beta$-actin antibody (Sigma-Aldrich, St. 144 Louis, MO, USA) as a control. Primary antibodies for phospho- and total mTOR were 145 supplied by Millipore (Billerica, MA, USA), those for phospho- and total IRE1 were 146 obtained from Abcam (Cambridge, UK), and the antibody against phospho- and total 147 JNK were purchased form Cell Signaling (Danvers, MA, USA). The rest of the antibodies 148 used were from Santa Cruz Biotechnologies (Dallas, TX, USA).

For hepatic histological analysis of Oil-Red-O-stained sections, the liver tissue was 151 perfused and fixed in 10\% paraformaldehyde solution before processing for paraffin 152 embedding. Images were acquired with an Olympus BX71 microscope equipped with a 153 DP72 camera and analyzed by a registered pathologist at BioBanc (Banc de tumors- 154 IDIBAPS, Barcelona Spain) who was unaware of the treatment groups. The area of 155 positive staining for Oil Red 0 was calculated as a percentage of stained cells/total 156 section area in each sample. Eight-micrometer serial sections of liver segments obtained 157 in a cryostat (Leyca CM-1900) at $-24^{\circ} \mathrm{C}$ were prepared and stained with hematoxylin- 158 eosin stain for histological evaluation of inflammatory structures. Lesion area was 159 quantified following the standard procedure by using Image-J software.

2.7. Enzyme activity assays

Hepatic fatty acid $\beta$-oxidation activity was determined in mice livers as previously 162 described [15] with $30 \mu \mathrm{g}$ of postnuclear supernatant.

Results are expressed as the mean of $n$ values \pm standard deviation (SD). Plasma and 165 lipid samples were assayed in duplicate. Significant differences between values from 166 control, fructose and Western groups were established by the one-way analysis of 167 variance test and Bonferroni posttest for selected comparisons; significant differences 168 between values from Western and Western + fructose groups were established by the 169 unpaired $t$ test (GraphPad Software V5). The level of statistical significance was set at 170 $P \leq .05$.

\section{Results}

3.1. Fructose supplementation did not change calorie intake, visceral 173 adipose tissue amount and body weight

After 12 weeks of intervention, total calorie intake significantly 175 increased in Western-diet-fed $v$ s. normal chow-fed mice $(\times 1.27$-fold $) 176$ but was not modified by supplementation with liquid fructose. Mice 177 ingesting the $15 \% \mathrm{w} / \mathrm{v}$ fructose solution compensated for the ingested 178 liquid calories by reducing the ingestion of the solid normal $(\times 0.72-179$ 
t1.1 Table 1

t1.2 Primers used for reverse transcriptase PCR $^{\mathrm{a}}$

$\mathrm{t} 1.3$

\begin{tabular}{|c|c|c|c|}
\hline Gene & GenBank no. & Primer sequences & $\begin{array}{l}\text { PCR } \\
\text { product }\end{array}$ \\
\hline Fos & NM_010234.2 & $\begin{array}{l}\text { Forward: 5'-TACTACCATTCCCCAGCCGA-3' } \\
\text { Reverse: 5'-GCTGTCACCGTGGGGATAAA-3' }\end{array}$ & 113 bp \\
\hline Ccr2 & NM_009915.2 & $\begin{array}{l}\text { Forward: 5'-AGAGGTCTCGGTTGGGTTGT-3' } \\
\text { Reverse: 5'-CACTGTCTTTGAGGCTTGTTGC-3' }\end{array}$ & 100 bp \\
\hline$C d 36$ & $\begin{array}{l}\text { NM_001159558. } \\
1\end{array}$ & $\begin{array}{l}\text { Forward: 5'-CCAAGCTATTGCGACATGATTAAT-3' } \\
\text { Reverse: 5'-CAATGTCCGAGACTTTTCAACAAA-3' }\end{array}$ & 75 bp \\
\hline Chop & NM_007837.4 & $\begin{array}{l}\text { Forward: 5'-TATCTCATCCCCAGGAAACG-3' } \\
\text { Reverse: 5'-GGGCACTGACCACTCTGTTT-3' }\end{array}$ & 219 bp \\
\hline Dgat2 & NM_026384.3 & $\begin{array}{l}\text { Forward: 5'-GCACAGACTGCTGGCTGATA-3' } \\
\text { Reverese: 5'-TTTCTTGGGCGTGTTCCAGT-3' }\end{array}$ & 71 bp \\
\hline Dnajb9 & NM_013760.4 & $\begin{array}{l}\text { Forward: 5'-TCTGCCTCAGAGCGACAAAT-3' } \\
\text { Reverse: 5'-TCCGACTATTGGCATCCGAG-3' }\end{array}$ & 145 bp \\
\hline Edem1 & NM_138677.2 & $\begin{array}{l}\text { Forward: 5'-CCAGCATGGGCTTCTACCAG-3' } \\
\text { Reverse: 5'-CCTTGGCCGATGAAGCCAG-3' }\end{array}$ & 119 bp \\
\hline$F 4 / 80$ & $\begin{array}{l}\text { XM_011246272. } \\
1\end{array}$ & $\begin{array}{l}\text { Forward: 5'-GGAGGACTTCTCCAAGCCT } \\
\text { Reverse: 5'-GGCCTCTCAGACTTCTGCTT }\end{array}$ & 69 bp \\
\hline Fasn & NM_007988.3 & $\begin{array}{l}\text { Forward: 5'-TCCTGGAACGAGAACAC } \\
\text { Reverse: 5'-GAGACGTGTCACTCCTG }\end{array}$ & 138 bp \\
\hline Gadd34 & NM_008654.2 & $\begin{array}{l}\text { Forward: 5'-TGCAAGGGGCTC } \\
\text { Reverse: 5'-ATTCTCAGCTGG }\end{array}$ & 104 bp \\
\hline Grp78 & $\begin{array}{l}\text { NM_001163434. } \\
1\end{array}$ & $\begin{array}{l}\text { Forward: 5'-ATTGGAGGT } \\
\text { Reverse: 5'-TCGCTGGGC }\end{array}$ & 150 bp \\
\hline Grp94 & NM_011631.1 & $\begin{array}{l}\text { Forward: 5'-GACCTTCGGGTTCGTCAGAG-3' } \\
\text { Reverse: 5'-AGCCTTCTCGGCTTTTACCC-3' }\end{array}$ & 83 bp \\
\hline Il-6 & $\begin{array}{l}\text { NM_001314054. } \\
1\end{array}$ & $\begin{array}{l}\text { Forward: 5'-ACACATGTTCTCTGGG } \\
\text { Reverse: 5'-AAGTGCATCATCGTTG }\end{array}$ & 84 bp \\
\hline Ccl2 & NM_011333.3 & $\begin{array}{l}\text { Forward: 5'-GCTGGAGAGCTACAAGAGGATCA-3' } \\
\text { Reverse: 5'-CTCTCTCTTGAGCTTGGTGACAAA-3' }\end{array}$ & 9 \\
\hline Myd88 & NM_010851.2 & $\begin{array}{l}\text { Forward: 5'-AGGCGATGAAGAAGGACTTTCC-3' } \\
\text { Reverse: 5'-TCAGTCTCATCTTCCCCTCTGC-3' }\end{array}$ & 163 bp \\
\hline Lep & NM_008493.3 & $\begin{array}{l}\text { Forward: 5'-AACCCTCATCAAGACCATTGTCA-3' } \\
\text { Reverse: 5'-CCTCTGCTTGGCGGATACC-3' }\end{array}$ & 73 bp \\
\hline Lepr & NM_146146.2 & $\begin{array}{l}\text { Forward: 5'-AACTGCAGTCTTCGGGGATG-3' } \\
\text { Reverse: 5'-ACTGAAAACTCACACCGGCA-3' }\end{array}$ & 109 bp \\
\hline Ppary & $\begin{array}{l}\text { XM_006505737. } \\
1\end{array}$ & $\begin{array}{l}\text { Forward: 5'-GCCCACCAACTTCGGAATC-3' } \\
\text { Reverse: 5'-TGCGAGTGGTCTTCCATCAC-3' }\end{array}$ & \\
\hline Scd1 & NM_009127.4 & $\begin{array}{l}\text { Forward: 5'-TTCCTTATCATTGCCAACACCAT-3' } \\
\text { Reverse: 5'-TGGGCGCGGTGATCTC-3' }\end{array}$ & $71 \mathrm{H}$ \\
\hline Tlr4 & NM_021297.2 & $\begin{array}{l}\text { Forward: 5'-GGCTCCTGGCTAGGACTCTGA-3' } \\
\text { Reverse: 5'-TCTGATCCATGCATTGGTAGGT-3' }\end{array}$ & 114 \\
\hline $\operatorname{Tnf} \alpha$ & NM_013693.3 & $\begin{array}{l}\text { Forward: 5'-GAAAAGCAAGCAGCCAACCA-3' } \\
\text { Reverse: 5'-CGGATCATGCTTTCTGTGCTC-3' }\end{array}$ & 106 bp \\
\hline Tbp & NM_013684.3 & $\begin{array}{l}\text { Forward: 5'-TGCCACACCAGCTTCTGAGA-3' } \\
\text { Reverse: 5'-TTTACAGCCAAGATTCACGGTAGA-3' }\end{array}$ & 9 bp \\
\hline
\end{tabular}

a All primers have been used at an efficiency between $85 \%$ and $110 \%$. fold $)$ or Western diet $(\times 0.82$-fold $)$ food. Only mice consuming the Western diet displayed increased final body weight $(\times 1.29 \mathrm{vs}$. control $)$ and visceral adipose tissue (vWAT) amount ( $\times 2.48$ vs. control, as a percentage of body weight) (Table 2). Despite that, the solid Western diet and liquid fructose supplementation induced hyperleptinemia ( $\times 5.50$ and $\times 2.29$, respectively) versus normal chow-fed mice values (Fig. 1A) and increased expression of the lep gene in vWAT (Fig. 1B). The sustained hyperleptinemia probably resulted in a state of peripheral leptin resistance, as liver expression of the SOCS-3 protein, an endogenous inhibitor of leptin signaling [16], was also increased in solid Western-diet-fed mice and liquid-fructose-supplemented mice (Fig. 1C). Accordingly, liver fos expression, which is controlled by leptin activity, was decreased, while the expression of the long form of the leptin receptor was increased [17] (Fig. 1D and E).

\subsection{Fructose supplementation did not result in hypertriglyceridemia or} worsened histological signs of fatty liver

There is a wealth of information describing the induction of hypertriglyceridemia and fatty liver by fructose supplementation in rats and humans [3,18-20]. However, in our study, liquid fructose supplementation in C57BL/6N mice consuming either control or a
Western diet did not induce hypertriglyceridemia or worsened fatty 200 liver (Fig. 2A-B). Although fructose supplementation in Western diet 201 mice significantly increased liver triglyceride accretion (Fig. 2C), 202 histological analysis of Oil-Red-O-stained sections (Fig. 2B) showed 203 exactly the same lipid percent area for Western-diet-fed mice, 204 irrespective of fructose supplementation $(11 \pm 12,12 \pm 3,100 \pm 0$ and 205 $100 \pm 0$ lipid percent area, expressed as mean $\pm S D$, for control, 206 fructose, Western and Western+fructose groups; $n=4$ for each 207 group). Accordingly, the amount of the lipogenic transcription factors 208 SREBP1c (mature form) and ChREBP in liver nuclear extracts was not 209 increased by fructose supplementation (Fig. 2D and E). The same was 210 observed with the hepatic expression of lipogenic enzymes (Fig. 2F) 211 (dgat2, scd1 and fasn). The lack of a clear lipogenic effect was not due 212 to a deficit in fructose incorporation into liver metabolism, as 213 fructokinase levels were increased in the livers of fructose- 214 supplemented mice (Fig. 2G). Fructose is known for inducing its 215 own metabolism by increasing the expression of the enzyme 216 fructokinase [21].

3.3. Fructose supplementation potentiated the hepatic cholesterol 218 burden in mice fed a solid Western diet

As the Western diet used in our experimental protocol contained 220 $0.21 \%$ of cholesterol, mice consuming this diet showed hypercholes- 221 terolemia and increased cholesterol deposition in liver tissue (Fig. 3A 222 and B). In addition, diets rich in saturated fat, like the Western diet 223 used in the present work, are known to induce hypertriglyceridemia 224 and fatty liver (Fig. 2) through the increased hepatic expression of the 225 nuclear receptor ppary and one of its target genes, $c d 36$ (Fig. 3C and 226 D), a fatty acid translocase [22]. Fructose supplementation did not 227 modify liver fatty acid $\beta$-oxidation activity (Fig. 3E). Surprisingly, 228 despite not affecting fatty acid synthesis and catabolism, liquid 229 fructose supplementation potentiated the increase of ppary and cd36 230 expression, as well as liver triglyceride and cholesterol accretion, in 231 Western-diet-fed mice (Figs. 2 and 3). This was observed despite a 232 significant reduction in the amount of the solid diet and thus dietary 233 cholesterol consumed by these mice (see above and Table 2). In 234 accordance with our previous results obtained in fructose- 235 supplemented rats [23], only fructose-supplemented mice showed 236 increased liver mTOR phosphorylation (Fig. 3F).

Table 2

Intake values (solid chow and supplemented beverage) and zoometric parameters for $C$, $\mathrm{F}, \mathrm{W}$ and $\mathrm{W}+\mathrm{F}$ expressed as mean $\pm \mathrm{SD}$ of the values obtained from at least eight different animals

\begin{tabular}{|c|c|c|c|c|}
\hline Parameter & C & $\mathrm{F}$ & W & $\mathrm{W}+\mathrm{F}$ \\
\hline $\begin{array}{c}\text { AUC }{ }^{\mathrm{a}} \text { beverage ( } \mathrm{ml} \text { per } \\
\text { mice per } 12 \text { weeks) }\end{array}$ & $374 \pm 57$ & $\begin{array}{l}524 \pm 35 \\
<.01 \times 1.40\end{array}$ & $\begin{array}{l}246 \pm 29 \\
<.05-34 \%\end{array}$ & $\begin{array}{l}312 \pm 14 \\
<.05 \text { vs. W } 1.27\end{array}$ \\
\hline $\begin{array}{l}\text { AUC }^{\mathrm{a}} \text { solid (g per mice } \\
\text { per } 12 \text { weeks) }\end{array}$ & $274 \pm 31$ & $\begin{array}{l}197 \pm 13 \\
<.05-28 \%\end{array}$ & $230 \pm 17$ & $\begin{array}{l}197 \pm 10 \\
<.05-14 \%\end{array}$ \\
\hline Ingested kcal from liquid & $0 \mathrm{kcal}$ & $314 \pm 21$ & $0 \mathrm{kcal}$ & $\begin{array}{l}187 \pm 8 \\
<.001 \text { vs. } \mathrm{F} \times 0.59\end{array}$ \\
\hline Ingested kcal from solid & $852 \pm 94$ & $\begin{array}{l}611 \pm 41 \\
<.05 \times 0.72\end{array}$ & $\begin{array}{l}1080 \pm 77 \\
<.05 \times 1.27\end{array}$ & $\begin{array}{l}925 \pm 49 \\
<.05 \text { vs. } \mathrm{W} \times 0.86\end{array}$ \\
\hline Total ingested calories & $852 \pm 94$ & $925 \pm 22$ & $\begin{array}{l}1080 \pm 37 \\
<.05 \times 1.27\end{array}$ & $1113 \pm 44$ \\
\hline $\begin{array}{l}\text { AUC }{ }^{\mathrm{a}} \text { body weight ( } \mathrm{g} \text { per } \\
\text { mice per } 12 \text { weeks) }\end{array}$ & $318.8 \pm 21.5$ & $315.8 \pm 21.9$ & $\begin{array}{l}369.2 \pm 26.5 \\
<.001 \times 1.17\end{array}$ & $358.3 \pm 33.9$ \\
\hline $\begin{array}{l}\text { Final body weight } \\
(\mathrm{BW})(\mathrm{g})\end{array}$ & $28.8 \pm 1.7$ & $29.5 \pm 2.9$ & $\begin{array}{l}37.1 \pm 3.6 \\
<.001 \times 1.29\end{array}$ & $37.1 \pm 4.7$ \\
\hline vWAT weight (g) & $0.8 \pm 0.2$ & $1.2 \pm 0.3$ & $\begin{array}{l}2.9 \pm 0.7 \\
<.001 \times 3.39\end{array}$ & $2.8 \pm 0.8$ \\
\hline$\%$ vWAT/BW & $3.2 \pm 0.06$ & $4.2 \pm 0.9$ & $\begin{array}{l}7.8 \pm 1.3 \\
<.001 \times 2.48\end{array}$ & $7.7 \pm 1.3$ \\
\hline Liver weight (g) & $1.4 \pm 0.2$ & $1.6 \pm 0.3$ & $1.7 \pm 0.4$ & $2.0 \pm 0.5$ \\
\hline
\end{tabular}

Statistical significance ( $P$ values $v s$. control group, if not indicated) and fold change are shown when appropriate.

a Area under the curve. 
A)

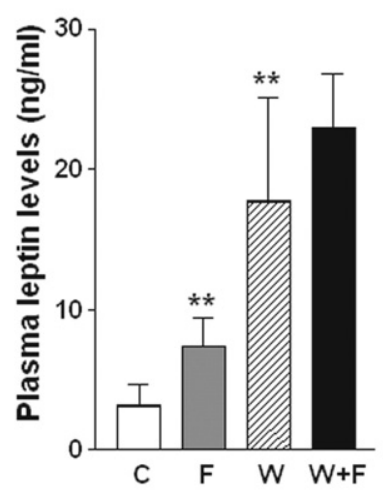

B)

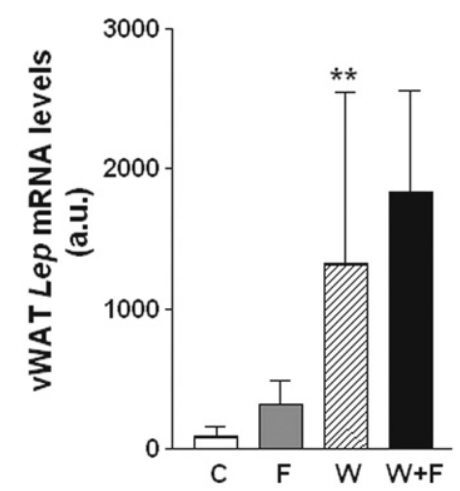

D)

E)
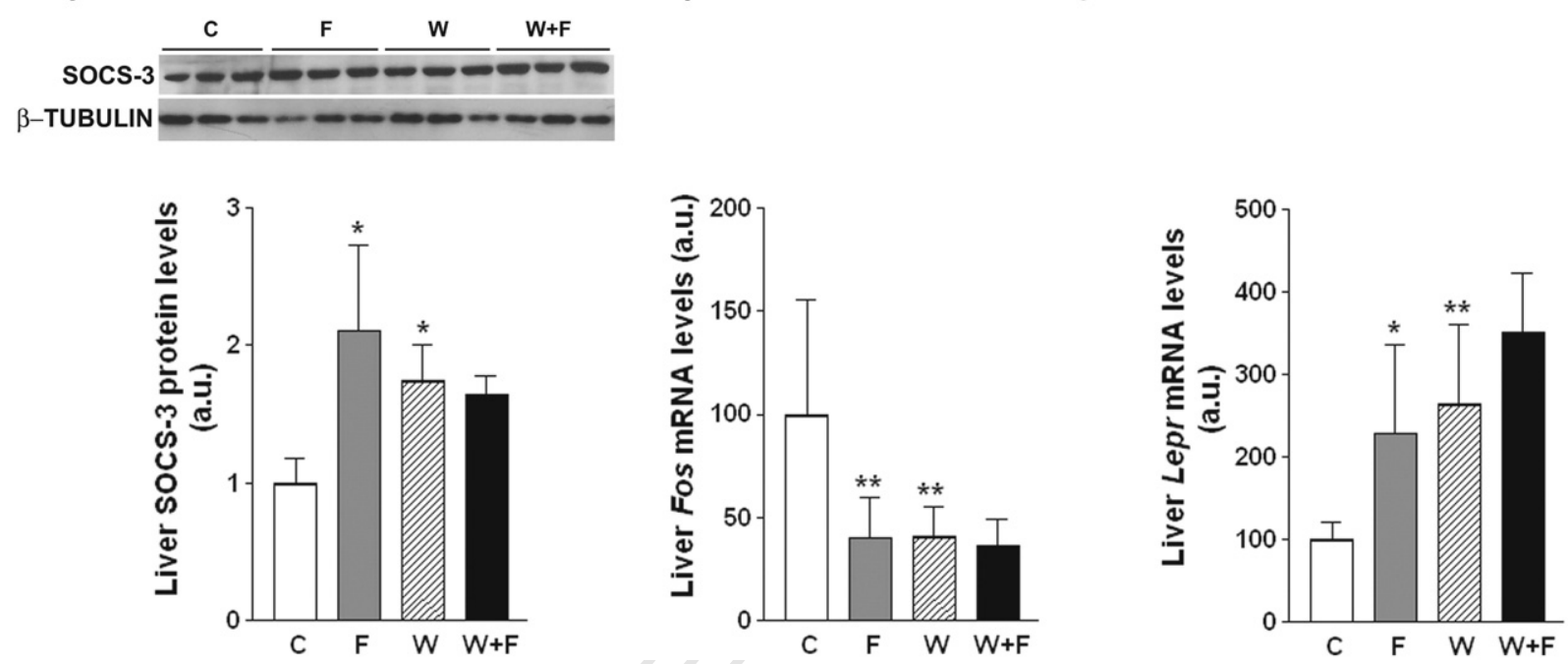

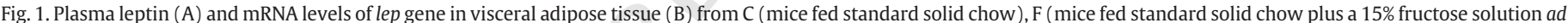

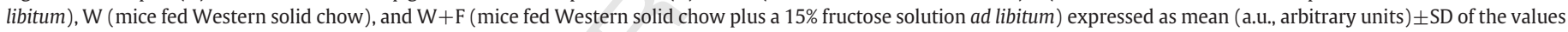

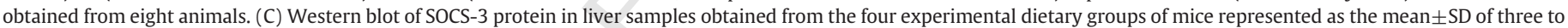

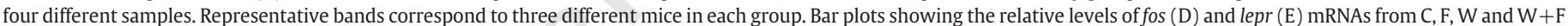
groups (mean \pm SD of four to six different liver samples). ${ }^{*} P<.05,{ }^{* *} P<.01$ vs. C values.

3.4. Inflammation was present, mainly in visceral adipose tissue, in mice consuming a solid Western diet irrespective of liquid fructose supplementation

Western diet consumption over 12 weeks increased the expression of $f 4 / 80$, a marker of macrophage infiltration and inflammatory markers, such as ccl2 and il-6, in mouse vWAT (Fig. 4A). Although there was a tendency to increased expression of inflammatory markers in the livers of Western-diet-fed mice, this was not statistically significant (Fig. 4B). Liver nuclear expression of p65 (Fig. 4C) and histological analysis of liver samples (Fig. 4D) confirmed the lack of a clear inflammatory process in this tissue. The expression of inflammatory markers activated by bacterial endotoxins, such as tlr4 or myd88, was not changed in the liver or adipose tissue of these mice. Moreover, fructose supplementation did not modify the expression of inflammatory markers, except in the cases of $\operatorname{tnf} \alpha$ and the chemokine receptor ccr2, which were significantly increased in vWAT when compared to the levels in mice consuming a 253 solid Western diet only.

3.5. Endoplasmic reticulum stress was not activated by any dietary 255 intervention

We have previously shown that fructose supplementation in rats 257 does not activate the endoplasmic reticulum stress (ERS) response 258 [23]. In the present study, neither liquid fructose supplementation nor 259 Western diet consumption affected the activation state of the PERK 260 and ATF6 branches of the ERS response (Fig. 5A and B). Consequently, 261 the expression of the target genes for activated PERK and ATF6 262 transcription factors was not changed or even decreased (Fig. 5C). 263

Phosphorylation and activation of IRE- 1 were increased by 264 Western diet consumption and, similar to our previous observations 265 in fructose-supplemented rats [23], liquid fructose supplementation 266

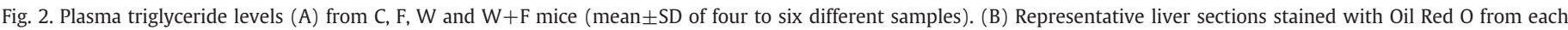

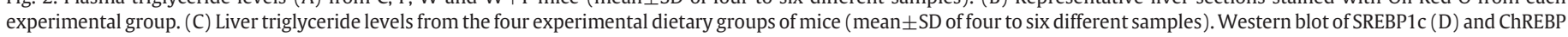

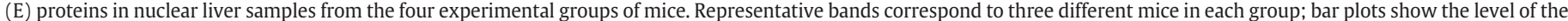

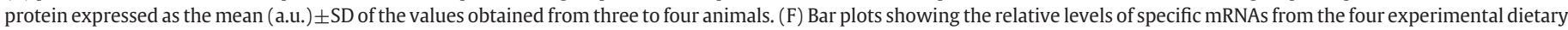

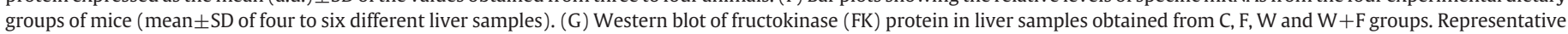

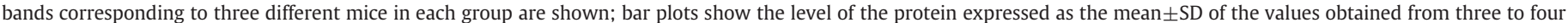
animals. ${ }^{*} P<.05,{ }^{* *} P<.01$ vs. $C$ values; \#\# $P<.01$ vs. W values. 
A)

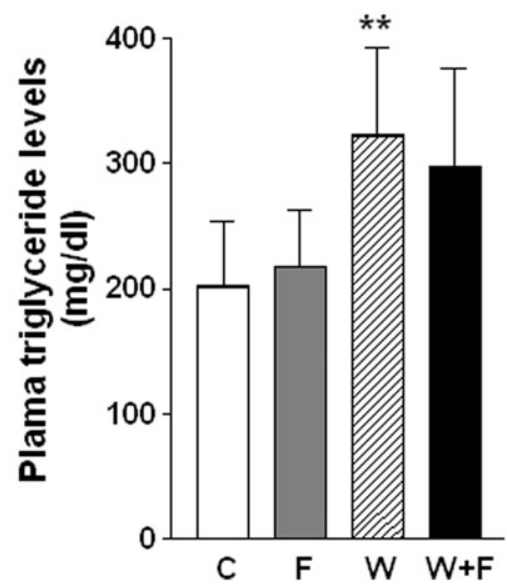

D)
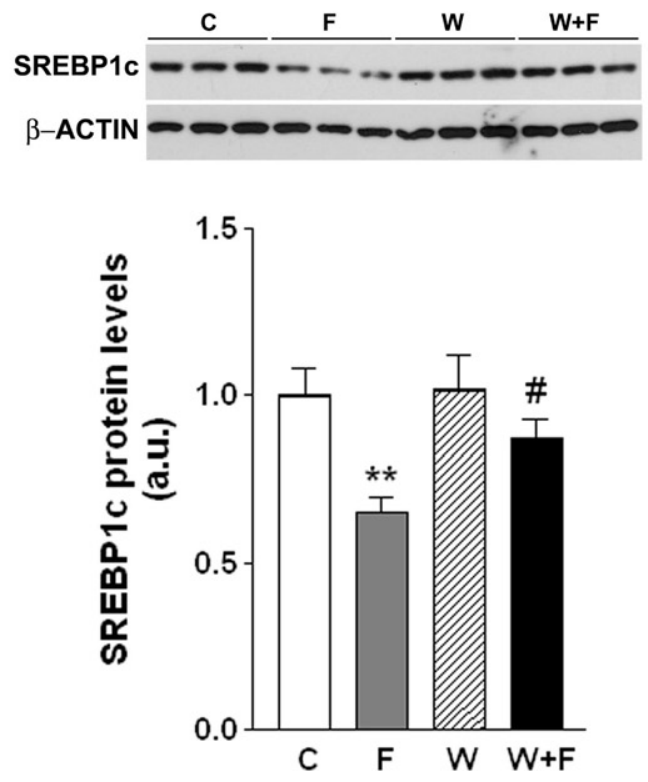

F)

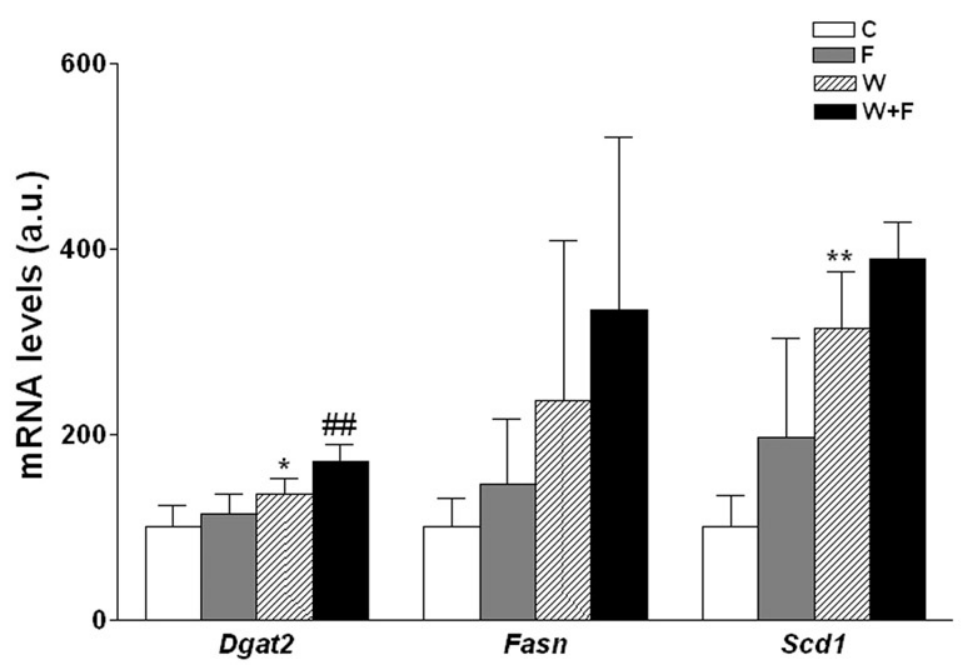

C)

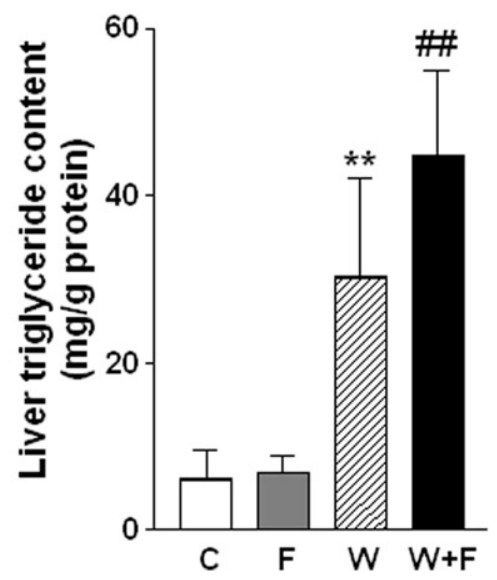

E)
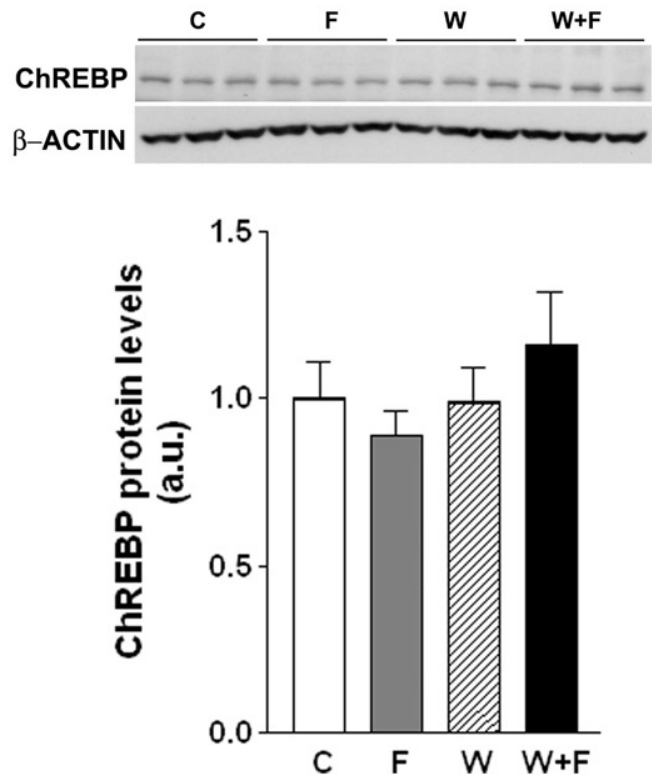

G)

$\beta$-TUBULIN

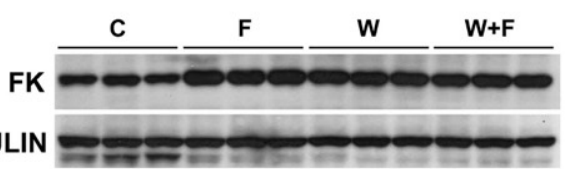

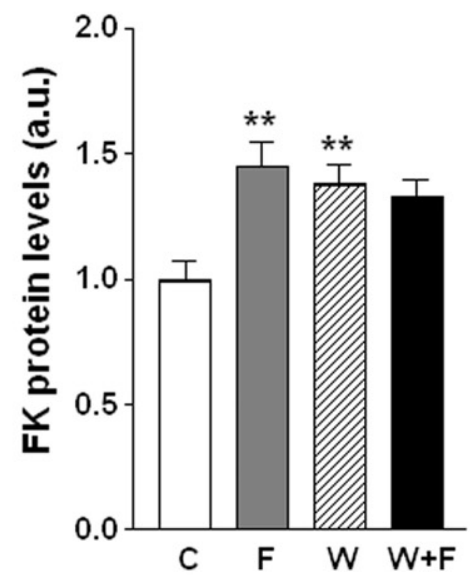


A)

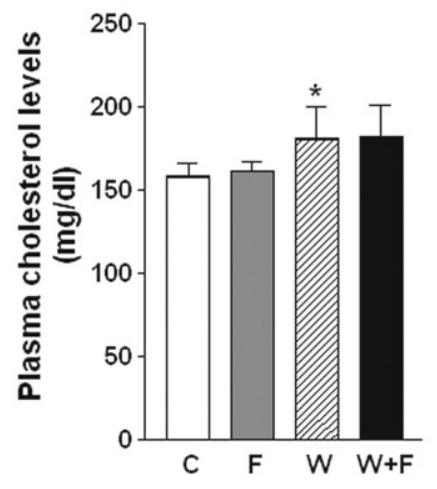

C)

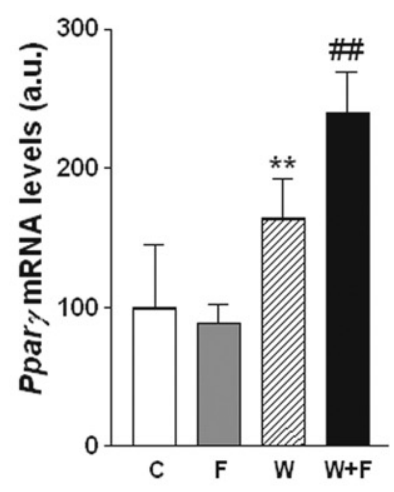

E)

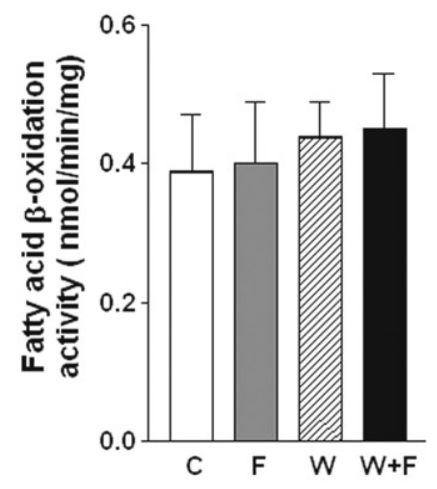

B)

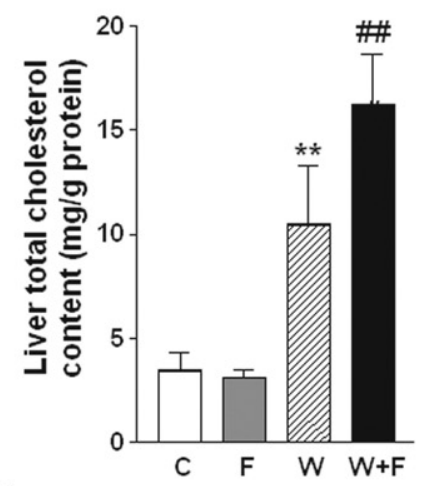

D)

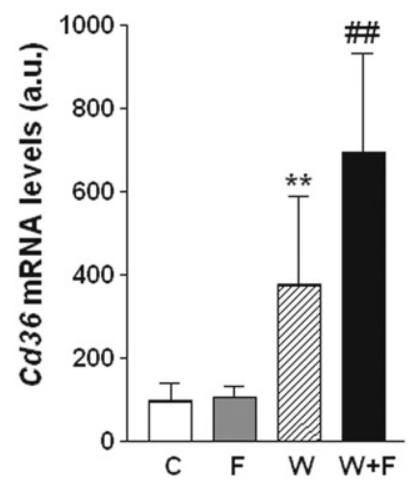

F)
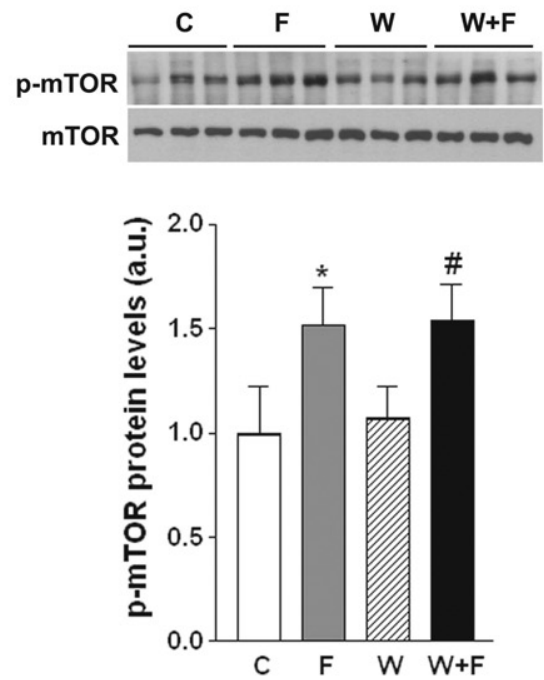

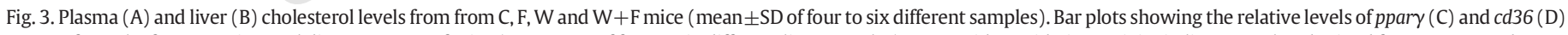

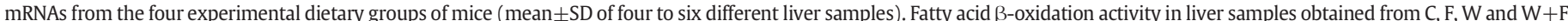

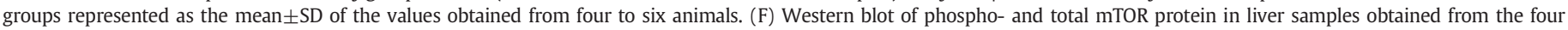

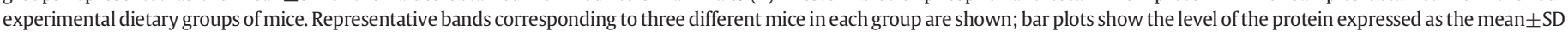
of the values obtained from three to four animals. ${ }^{*} P<.05,{ }^{* *} P<.01$ vs. C values; $\# P<.05$, \#\# $P<.01$ vs. W values.

(Fig. 5D). However, this activation did not translate into an increased expression of the spliced XBP1 (XBP1s) transcription factor in all the dietary intervention groups (Fig. 5E), as demonstrated by the unaltered or even decreased expression of XBP1s target genes (Fig. 5C). Moreover, there was no clear increase in the activated, phosphorylated form of JNK (Fig. 5F).
3.6. Only the combination of a Western diet and liquid fructose 273 supplementation significantly reduced the ISI in mice

No dietary intervention significantly modified plasma glucose (Fig. 6A) 275 and insulin (Fig. 6B) concentrations, although mice fed a Western diet 276 showed a tendency towards increased glucose and insulin levels, an 277 
A)

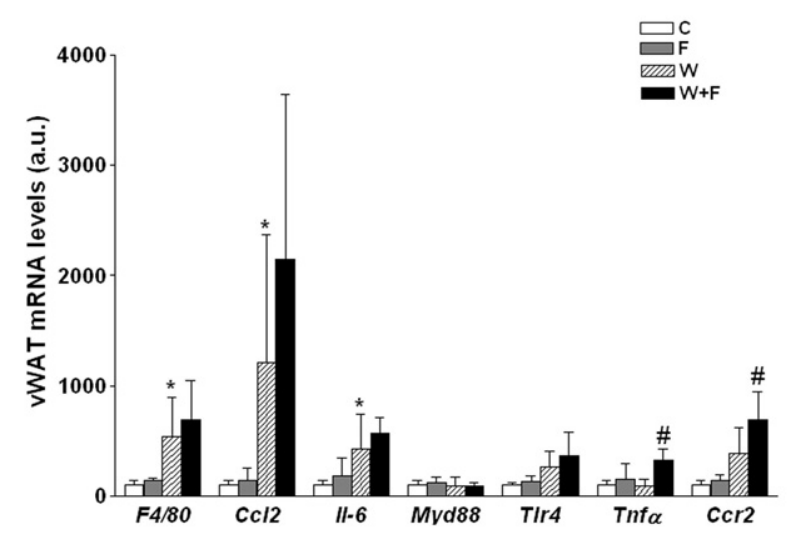

C)
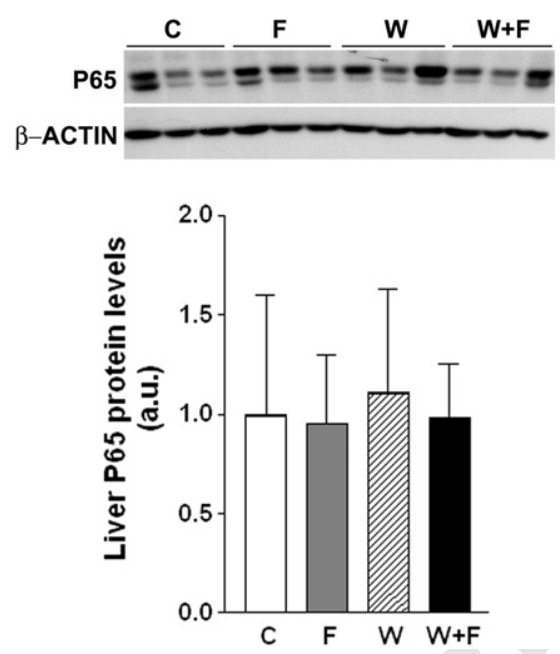

B)

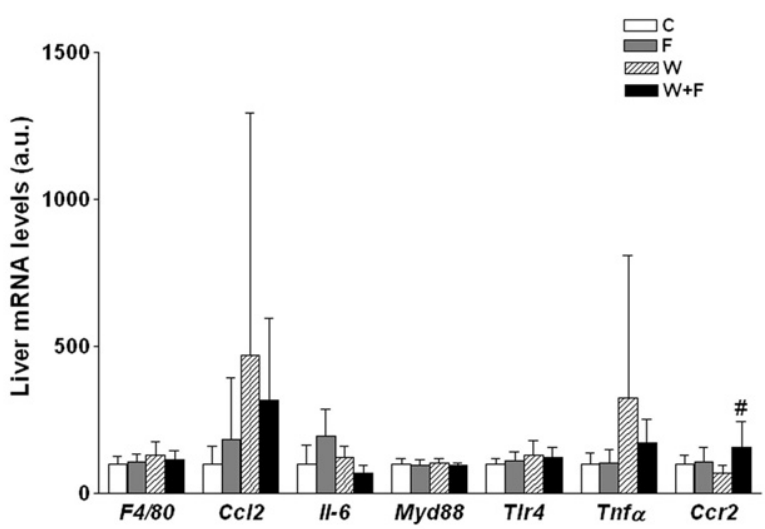

D)

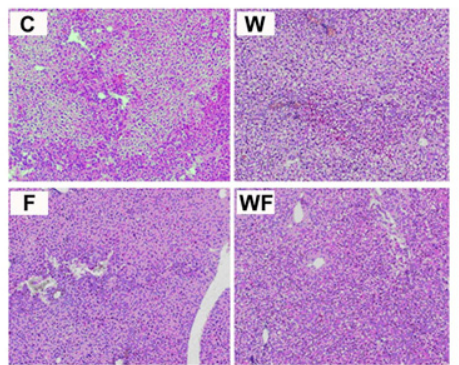

effect that was further magnified with liquid fructose supplementation. As a consequence, the ISI was only significantly reduced in the Westerndiet-fed mice supplemented with fructose (W+F mice) (Fig. 6C). We have previously shown that liquid fructose supplementation reduces rat liver IRS2 protein content $[24,25]$. As IRS2 is a key molecule in the insulin signaling pathway [26], we measured IRS2 protein levels in our liver samples. We found a progressive reduction in IRS2 protein levels across the different intervention dietary groups that was significant in Western-fed mice, further increased to less than half the value present in controls in $\mathrm{W}+\mathrm{F}$ animals (Fig. 6D).

\section{Discussion}

Epidemiological studies in humans point to the high consumption of fructose-enriched beverages as a key factor in the development of obesity, T2DM and associated cardiovascular comorbidities. Here we show in an experimental dietary intervention model, the C57BL/6N mouse, whose metabolism is responsive to dietary manipulation that liquid fructose supplementation promotes hepatic cholesterol and triglyceride accretion, a deficit in liver insulin signaling and a reduction in whole-body insulin sensitivity in a background of an unhealthy, Western-style diet. These effects were observed despite total calorie intake remaining exactly the same between nonsupple- 298 mented and supplemented animals.

Increased energy intake without a corresponding increase in 300 calorie expenditure by physical activity, thermoregulation, etc., leads 301 to an energy imbalance that results in increased body weight, mainly 302 through an expansion of visceral adipose tissue [27]. Thus, in our 303 present work, mice consuming a high-energy-density diet, such as the 304 Western-type diet we used, increased their energy intake by $\times 1.27305$ when compared to control animals, consequently increasing their 306 body weight mainly through a marked accretion of visceral adipose 307 tissue (Table 2). Although Western-diet-fed mice were hyperleptine- 308 mic, they did not compensate for the excess of calories ingested by 309 reducing the total amount of solid food consumed, thereby indicating a 310 state of leptin resistance. Indeed, we provide evidence for leptin 311 resistance in the peripheral tissues of Western-diet-fed animals (Fig. 1). 312 Hypertriglyceridemia has been proposed to be key in reducing leptin 313 penetration in the central nervous system and thus inducing central 314 leptin resistance [28]. Given that Western-diet-fed mice showed 315 marked hypertriglyceridemia (Fig. 2), this could be responsible for the 316 lack of calorie compensation. This is in accordance with the fact that, 317 although mice supplemented with liquid fructose showed hyperlepti- 318 nemia and manifestations of peripheral leptin resistance (Fig. 1), they 319 
A)
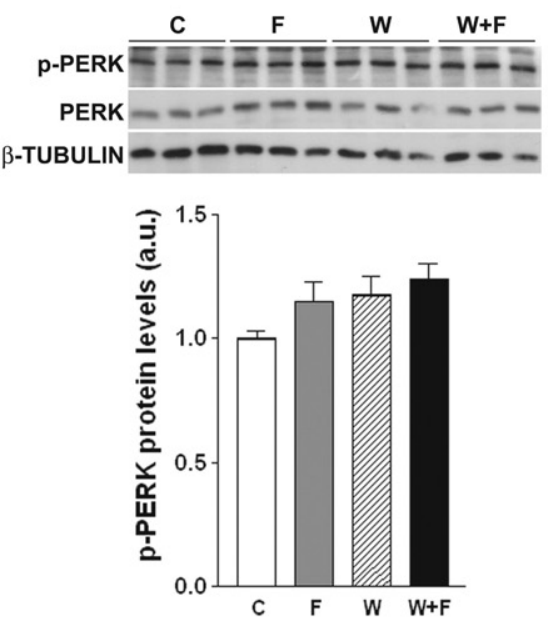

C)

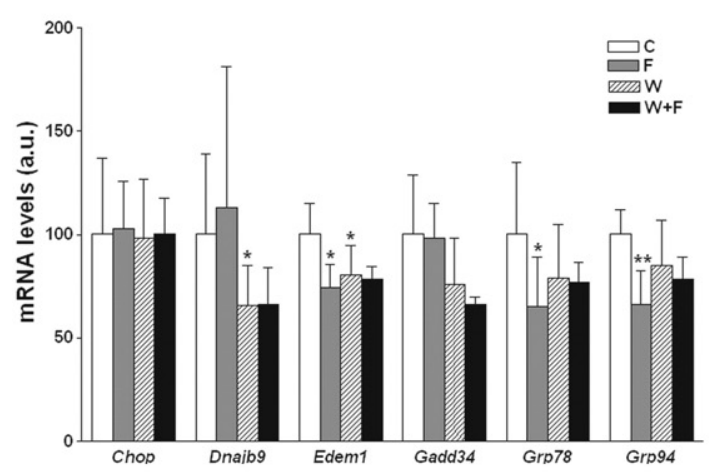

E)
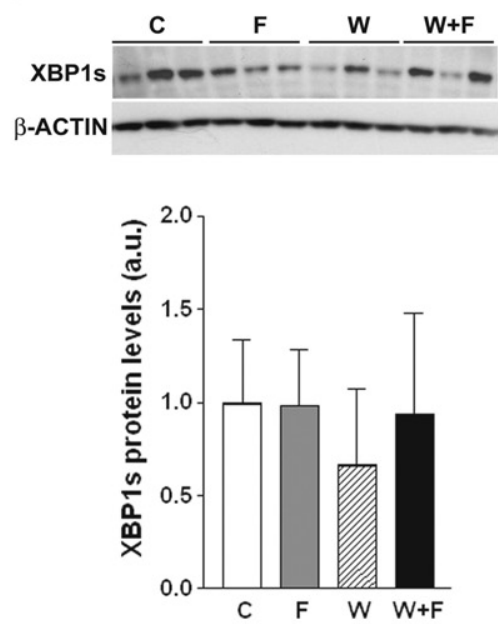

B)
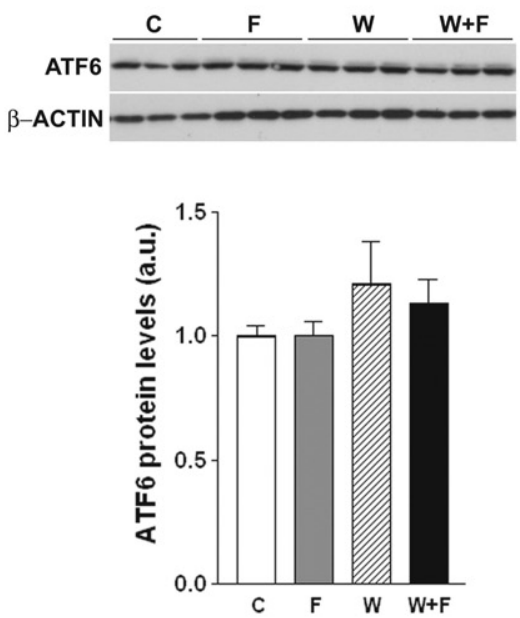

D)
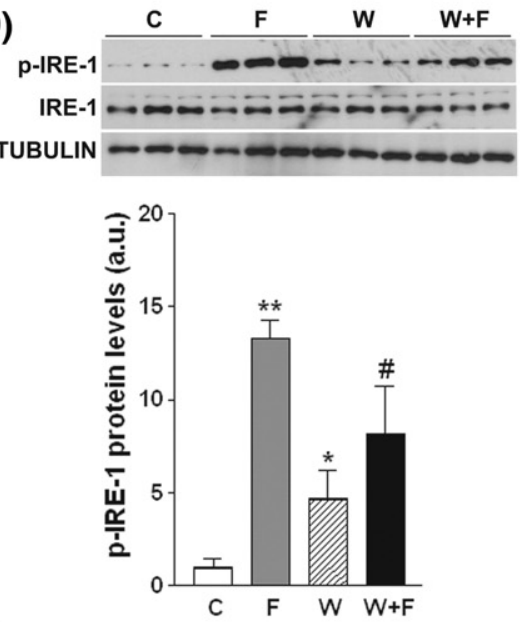

F)
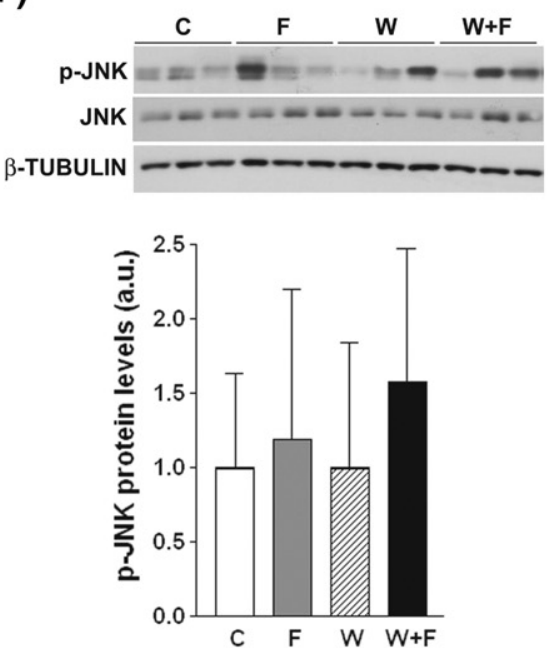

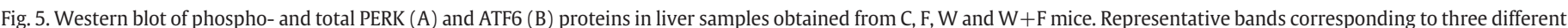

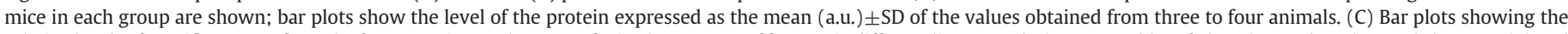

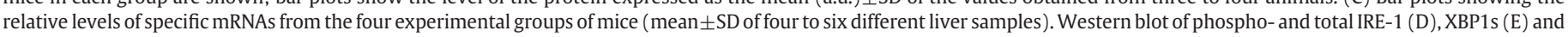

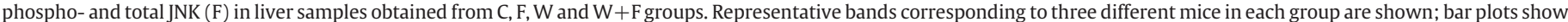
the level of the protein expressed as the mean \pm SD of the values obtained from three to four animals. ${ }^{*} P<.05,{ }^{* *} P<.01$ vs. $C$ values; \#P<.05 vs. W values.

did not present hypertriglyceridemia, and consequently, they did compensate for the increased amount of fructose-derived calories by reducing the quantity of solid food consumed. Thus, body weight and the amount of visceral adipose tissue did not change in liquid- fructose-supplemented mice with respect to their corresponding 324 controls (Table 2).

The lack of hypertriglyceridemia and liver steatosis in fructose- 326 supplemented mice was rather surprising given the wealth of 327 
A)

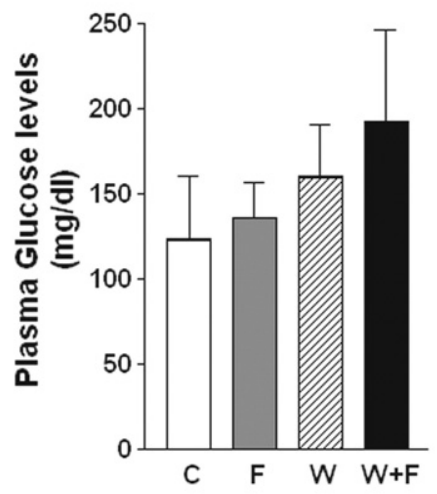

C)

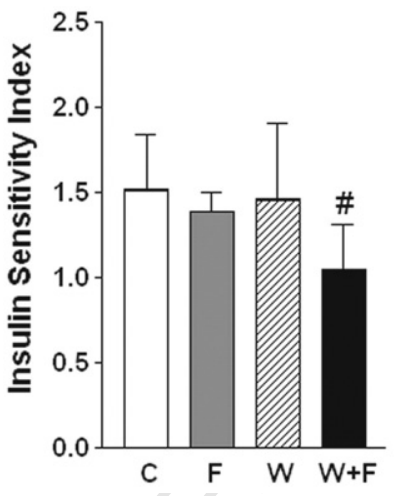

B)

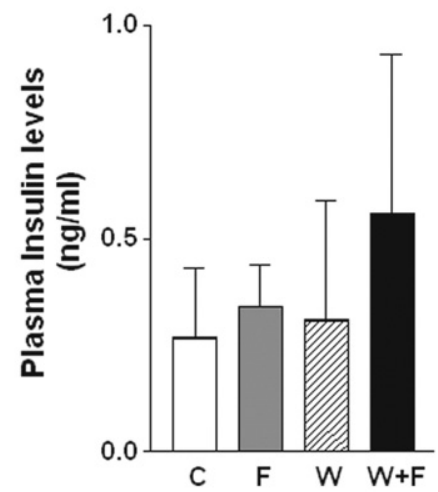

D)
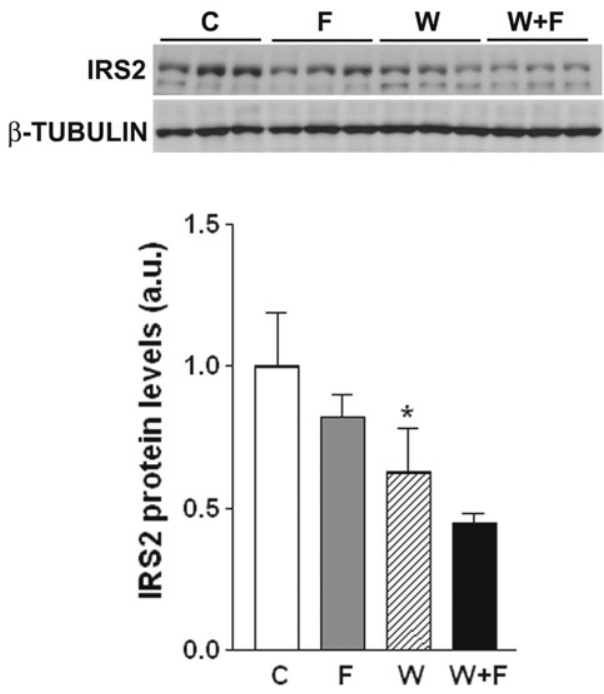

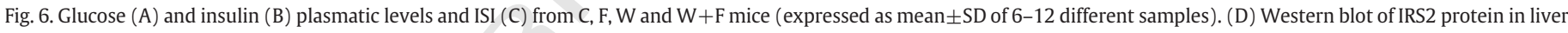

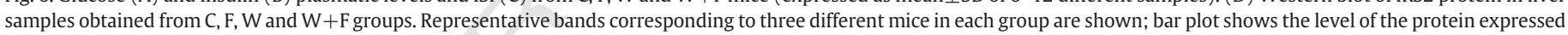
as the mean (a.u.) \pm SD of the values obtained from three to four animals. ${ }^{*} P<.05$; $\# P<.05$ vs. W values.

information on fructose and increased liver lipogenesis [20] and our previous study with $10 \% \mathrm{w} / \mathrm{v}$ liquid-fructose-supplemented rats [19]. We have previously shown in rats that fructose is more lipogenic than glucose because the former not only directly increases liver lipogenesis but also reduces liver fatty acid $\beta$-oxidation activity $[6,7]$. As mice, unlike rats and humans, are able to transform a considerable amount of fructose into glucose in the intestinal tract [29], one possible explanation for our present results is that the total amount of fructose reaching the liver was not enough to stimulate lipogenesis and also reduce fatty acid oxidation. In fact, when a higher fructose solution is used ( $30 \% \mathrm{w} / \mathrm{v}$, see work from the Bergheim group [9]), a clear lipogenic effect is observed in mice but at the expense of changing intestinal permeability that allows the presence of bacterial endotoxins in portal blood and the development of liver TLR4-mediated inflammation [8]. In our mice, fructose supplementation did not increase the expression of inflammatory markers in liver, including endotoxin-related markers such as tlr4 and myd88. An increase in inflammatory markers not related to bacterial endotoxins was only detected in visceral adipose tissue from Western-diet-fed mice. Similarly to our previous observations in rat [23], fructose supple- mentation did not induce an ERS response. Only the IRE-1 pathway 348 seemed to be activated; however, there were no discernible changes in 349 the downstream targets of IRE-1, either as a kinase, leading to the 350 activation of JNK, or as RNA splicing enzyme, leading to XPB1s' 351 increased expression and transcriptional activity. The consumption of 352 a solid Western diet had a similar, but small, effect on IRE-1 activation 353 as fructose supplementation in the mice. Again, like our previous 354 results in rats [23], we observed increased mTORC1 phosphorylation 355 in the livers of fructose-supplemented mice. mTORC1 activation has 356 been linked to specific stimulation of the IRE-1 pathway [30], possibly 357 explaining the specific and intense increase in IRE-1 phosphorylation 358 observed in fructose-supplemented mice. It is interesting to note that 359 IRE- 1 activation has been directly linked to the prevention of hepatic 360 steatosis [31]. In this sense, the strong increase in IRE-1 phosphory- 361 lation in fructose-supplemented mouse livers could explain the 362 absence of a lipogenic response in these animals.

Despite the lack of a lipogenic effect, fructose supplementation 364 clearly increased liver triglyceride and cholesterol deposition in mice 365 consuming a solid Western diet, although these animals did reduce 366 their consumption of the solid diet and maintained an isocaloric intake 367 
1] The InterAct consortium. Consumption of sweet beverages and type 2 diabetes incidence in European adults: results from EPIC-InterAct; 2013. Diabetologia 56: 1520-30. http://dx.doi.org/10.1007/s00125-013-2899-8.

[2] Malik VS, Popkin BM, Bray GA, Després J-P, Hu FB. Sugar-sweetened beverages, obesity, type 2 diabetes mellitus, and cardiovascular disease risk; 2010.
Circulation 121:1356-64. http://dx.doi.org/10.1161/CIRCULATIONAHA.109. 425 876185.

[3] Stanhope KL, Schwarz JM, Keim NL, Griffen SC, Bremer AA, Graham JL, et al. 427 Consuming fructose-sweetened, not glucose- sweetened, beverages increases 428 visceral adiposity and lipids and decreases insulin sensitivity in overweight / 429 obese humans; 2009. J Clin Invest 119:1322-34. http://dx.doi.org/10.1172/ 430 JCl37385DS1.

[4] Ebbeling CB, Feldman HA, Chomitz VR, Antonelli TA, Gortmaker SL, Osganian SK, 432 et al. A randomized trial of sugar-sweetened beverages and adolescent body 433 weight; 2012. N Engl J Med 367:1407-16. http://dx.doi.org/10.1056/ 434 NEJMoa1203388.

[5] Lê KA, Faeh D, Stettler R, Ith M, Kreis R, Vermathen P, et al. A 4-wk high-fructose 436 diet alters lipid metabolism without affecting insulin sensitivity or ectopic lipids 437 in healthy humans. Am J Clin Nutr 2006;84:1374-9. 438

[6] Roglans N, Vilà L, Farré M, Alegret M, Sánchez RM, Vázquez-Carrera M, et al. 439 Impairment of hepatic Stat-3 activation and reduction of PPARalpha activity in 440 fructose-fed rats; 2007. Hepatology 45:778-88. http://dx.doi.org/10.1002/hep. 441 21499.

[7] Rebollo A, Roglans N, Baena M, Sánchez RM, Merlos M. Liquid fructose 443 downregulates Sirt1 expression and activity and impairs the oxidation of fatty 444 acids in rat and human liver cells. Biochim Biophys Acta 1841;2014:514-24. 445

[8] Spruss A, Kanuri G, Wagnerberger S, Haub S, Bischoff SC, Bergheim I. Toll-like 446 receptor 4 is involved in the development of fructose-induced hepatic steatosis in 447 mice. Hepatology 2009;50:1094-104.

[9] Bergheim I, Weber S, Vos M, Krämer S, Volynets V, Kaserouni S, et al. Antibiotics protect 449 against fructose-induced hepatic lipid accumulation in mice: role of endotoxin; 2008.J 450 Hepatol 48:983-92. http://dx.doi.org/10.1016/j.jhep.2008.01.035. 451

[10] Hutter N, Baena M, Sangüesa G, Dávalos A, Latasa MJ, Escolà-Gil JC, et al. Liquid 452 fructose supplementation in LDL-R-/ - mice fed a Western-type diet enhances 453 lipid burden and atherosclerosis despite identical calorie consumption; 2015. IJC 454 Metab Endocr 9:12-21. http://dx.doi.org/10.1016/j.ijcme.2015.10.002. 455

[11] Helenius M, Hänninen M, Lehtinen S, Salminen A. Aging-induced up-regulation of 456 nuclear binding activities of oxidative stress responsive NF-kB transcription factor 457 in mouse cardiac muscle. J Mol Cell Cardiol 1996;28:487-98. 458

[12] Bradford M. A rapid and sensitive method for quantitation of microgram 459 quantities of protein utilizing the principle of protein-dye binding. Anal Biochem 460 1976;72:248-54.

[13] Qu S, Su D, Altomonte J, Kamagate A, He J, Perdomo G, et al. PPAR\{alpha\} mediates 462 the hypolipidemic action of fibrates by antagonizing FoxO1; 2007. Am J Physiol 463 Endocrinol Metab 292:E421-34. http://dx.doi.org/10.1152/ajpendo.00157.2006. 464

[14] Bligh EG, Dyer WJ. A rapid method of total lipid extraction and purification. Can J 465 Biochem Physiol 1959;37:911-7. 466

[15] Lazarow P. Assay of peroxisomal beta-oxidation of fatty acids. Methods Enzymol 467 1981;72:315-9.

[16] Howard JK, Flier JS. Attenuation of leptin and insulin signaling by SOCS proteins; 2006. 469 Trends Endocrinol Metab 17:365-71. http://dx.doi.org/10.1016/j.tem.2006.09.007. 470

[17] Cohen P, Yang G, Yu X, Soukas AA, Wolfish CS, Friedman JM, et al. Induction of 471 leptin receptor expression in the liver by leptin and food deprivation *; 2005.J Biol 472 Chem 280:10034-9. http://dx.doi.org/10.1074/jbc.M413684200. 473

[18] Havel PJ. Dietary fructose: implications for dysregulation of energy homeostasis 474 and lipid/carbohydrate metabolism; 2005. Nutr Rev 63:133-57. http://dx.doi.org/ 475 10.1111/j.1753-4887.2005.tb00132.x.

[19] Rebollo A, Roglans N, Alegret M, Laguna JC. Way back for fructose and liver 477 metabolism: bench side to molecular insights; 2012. World J Gastroenterol 18: 478 6552-9. http://dx.doi.org/10.3748/wjg.v18.i45.6552. 479

[20] Ouyang X, Cirillo P, Sautin Y, McCall S, Bruchette JL, Diehl AM, et al. Fructose 480 consumption as a risk factor for non-alcoholic fatty liver disease; 2008. J Hepatol 481 48:993-9. http://dx.doi.org/10.1016/j.jhep.2008.02.011.

[21] Vilà L, Rebollo A, Ađalsteisson GS, Alegret M, Merlos M, Roglans N, et al. Reduction 483 of liver fructokinase expression and improved hepatic inflammation and 484 metabolism in liquid fructose-fed rats after atorvastatin treatment; 2011. Toxicol 485 Appl Pharmacol 251:32-40. http://dx.doi.org/10.1016/j.taap.2010.11.011. 486

[22] Musso G, Gambino R, Cassader M. Recent insights into hepatic lipid metabolism in 487 non-alcoholic fatty liver disease (NAFLD); 2009. Prog Lipid Res 48:1-26. http://dx. 488 doi.org/10.1016/j.plipres.2008.08.001. 489

[23] Baena M, Sangüesa G, Hutter N, Sánchez RM, Roglans N, Laguna JC, et al. Fructose 490 supplementation impairs rat liver autophagy through mTORC activation without 491 inducing endoplasmic reticulum stress; 1851. Biochim Biophys Acta 2015: 492 107-16. http://dx.doi.org/10.1016/j.bbalip.2014.11.003. 493

[24] Vilà L, Roglans N, Perna V, Sánchez RM, Vázquez-Carrera M, Alegret M, et al. Liver 494 AMP/ATP ratio and fructokinase expression are related to gender differences in 495 AMPK activity and glucose intolerance in rats ingesting liquid fructose; 2011. J 496 Nutr Biochem 22:741-51. http://dx.doi.org/10.1016/j.jnutbio.2010.06.005. 497

[25] Rebollo A, Roglans N, Baena M, Padrosa A, Sánchez RM, Merlos M, et al. Liquid 498 fructose down-regulates liver insulin receptor substrate 2 and gluconeogenic 499 enzymes by modifying nutrient sensing factors in rats; 2014. J Nutr Biochem 25: 500 250-8. http://dx.doi.org/10.1016/j.jnutbio.2013.10.014. 501

[26] Kubota N, Tobe K, Terauchi Y, Eto K, Yamauchi T, Suzuki R, et al. Disruption of insulin 502 receptor substrate 2 causes type 2 diabetes because of liver insulin resistance and lack of 503 compensatory beta-cell hyperplasia. Diabetes 2000;49:1880-9.

[27] Tchernof A, Despres J-P. Pathophysiology of human visceral obesity: an update; 505 2013. Physiol Rev 93:359-404. http://dx.doi.org/10.1152/physrev.00033.2011. 506

[28] Banks WA, Coon AB, Robinson SM, Moinuddin A, Shultz JM, Nakaoke R, et al. 507 Triglycerides induce leptin resistance at the blood-brain barrier; 2004. Diabetes 508 53:1253-60. http://dx.doi.org/10.2337/diabetes.53.5.1253. 
510 [29] Mayes P. Intermediary metabolism of fructose. Am J Clin Nutr 1993;58:754S-65S.

511 [30] Kato H, Nakajima S, Saito Y, Takahashi S, Katoh R, Kitamura M. mTORC1 serves ER (1) steatosis; 2011. Embo J 30:1357-75. http://dx.doi.org/10.1038/emboj.2011.52 emboj201152 [pii]|r].

[32] Wilson C, Tran J, Erion D, Vera N, Febbraio M, Weiss E. Hepatocyte-spcific disruption of CD36 attenuates fatty liver and improves insulin sensitivity in HFD fed mice. Endocrinology 2015.
[33] Wang BT, Ducker GS, Barczak AJ, Barbeau R, Erle DJ, Shokat KM. The mammalian 521 target of rapamycin regulates cholesterol biosynthetic gene expression and 522 exhibits a rapamycin-resistant transcriptional profile; 2011. Proc Natl Acad Sci U S 523 A 108:15201-6. http://dx.doi.org/10.1073/pnas.1103746108.

[34] Wang C, Yan Y, Hu L Z Zao L Yang P. Moorhead JF, et al Rapamycin-mediated CD36 525 translational suppression contributes to alleviation of hepatic steatosis; 2014. Biochem 526 Biophys Res Commun 447:57-63. http://dx.doi.org/10.1016/j.bbrc.2014.03.103. 527
[35] Wang C, Hu L, Zhao L, Yang P, Moorhead JF, Varghese Z, et al. Inflammatory stress 528 increases hepatic CD36 translational efficiency via activation of the mTOR 529 signalling pathway; 2014. PLoS One 9:1-12. http://dx.doi.org/10.1371/journal. 530 pone.0103071. 